Basic Health Sciences

Poster

Abstract ID: 132

\title{
Antibacterial activities of Protein Extracts From Andrographis Paniculata, Tinospora Crispa and Centella Asiatica
}

Noor Hasniza Zin | Nurul Fatihah Ahmad | Noraslinda Muhamad Bunnori | Widya Abdul Wahab | Normah Haron

Kulliyyah of Science, International Islamic University Malaysia

Introduction: Andrographis paniculata, Tinospora crispa and Centella asiatica are known to have various pharmacological functions. This research was carried out to investigate the antibacterial activities of protein extracts from $A$. paniculata, T. crispa and $C$. asiatica._Methods: Total soluble proteins from these herbs were extracted using a modified TCA/acetone method. The protein extracts were then quantified using the Bradford assay and separated using SDS-PAGE. The antibacterial activities were determined by disc diffusion method. Results: $T$. crispa had a significantly higher amount of proteins $(83.86 \pm 0.4 \mu \mathrm{g} / \mu \mathrm{l})$ compared to $A$. paniculata $(81.57 \pm 0.4 \mu \mathrm{g} / \mu \mathrm{l})$ and $C$. asiatica $(78.93 \pm 0.5 \mu \mathrm{g} / \mu \mathrm{l})$. The proteins separated by SDS-PAGE were ranged from $30 \mathrm{kDa}$ to $260 \mathrm{kDa}, 25 \mathrm{kDa}$ to $110 \mathrm{kDa}$ and $25 \mathrm{kDa}$ to $160 \mathrm{kDa}$ for $A$. paniculata, $T$. crispa and $C$. Asiatic, respectively. The high abundance proteins were observed in $A$. paniculata and $T$. crispa but not in $C$. asitica. Protein extracts from $C$. asiatica have demonstrated antibacterial activity against all tested bacteria with the diameter of inhibition zone of $11.0 \pm 0.5 \mathrm{~mm}, 12.3 \pm 0.6 \mathrm{~mm}, 10.7 \pm 0.7 \mathrm{~mm}$ and $20.0 \pm 0.8 \mathrm{~mm}$ against B. cereus, $\mathrm{S}$. aureus, $K$. pneumonia and S. typhimurium respectively. Meanwhile, protein extracts of $A$. paniculata showed a positive antibacterial activity only against $B$.cereus $(13.7 \pm 0.4 \mathrm{~mm})$, S. aureus $(7.0 \pm 0.8 \mathrm{~mm})$ and S. typhimurium $(11.5 \pm 0.3 \mathrm{~mm})$. Protein extracts from $T$. crispa only showed a positive antibacterial activity against $B$. cereus $(9.7 \pm 0.5 \mathrm{~mm})$. Conclusions: There is a constant need in the discovery of new antibiotics for the treatment of infectious diseases.

KEYWORDS: SDS-PAGE, soluble protein, disc diffusion, antibacteria 